\title{
The association between obesity and outcomes in critically ill patients
}

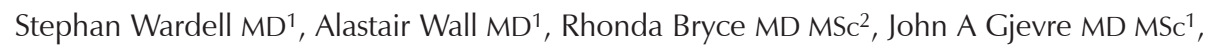 \\ Karen Laframboise $\mathrm{MD}^{1}$, John $\mathrm{K}$ Reid $\mathrm{MD}^{1}$
}

\begin{abstract}
S Wardell, A Wall, R Bryce, JA Gjevre, K Laframboise, JK Reid. The association between obesity and outcomes in critically ill patients. Can Respir J 2015;22(1):23-30.
\end{abstract}

BACKGROUND: Obesity rates are increasing worldwide, particularly in North America. The impact of obesity on the outcome of critically ill patients is unclear.

METHODS: A prospective observational cohort study of consecutive patients admitted to a tertiary critical care unit in Canada between January 10, 2008 and March 31, 2009 was conducted. Exclusion criteria were age $<18$ years, admission $<24 \mathrm{~h}$, planned cardiac surgery, pregnancy, significant ascites, unclosed surgical abdomen and brain death on admission. Height, weight and abdominal circumference were measured at the time of intensive care unit (ICU) admission. Coprimary end points were ICU mortality and a composite of ICU mortality, reintubation, ventilator-associated pneumonia, line sepsis and ICU readmission. Subjects were stratified as obese or nonobese, using two separate metrics: body mass index (BMI) $\geq 30 \mathrm{~kg} / \mathrm{m}^{2}$ and a novel measurement of 75 th percentile for waist-toheight ratio (WHR).

RESULTS: Among 449 subjects with a BMI $\geq 18.5 \mathrm{~kg} / \mathrm{m}^{2}$, both BMI and WHR were available for comparative analysis in 348 (77.5\%). Neither measure of obesity was associated with the primary end points. BMI $\geq 30 \mathrm{~kg} / \mathrm{m}^{2}$ was associated with a lower odds of six-month mortality than the BMI $<30 \mathrm{~kg} / \mathrm{m}^{2}$ group (adjusted OR 0.59 [95\% CI 0.36 to 0.97]; $\mathrm{P}=0.04$ ) but longer intubation times (adjusted RR 1.56 [95\% CI 1.17 to 2.07]; $\mathrm{P}=0.003$ ) and longer ICU length of stay (adjusted RR 1.67 [95\% CI 1.21 to 2.31]; $\mathrm{P}=0.002$ ). Conversely, measurement of 75 th percentile for WHR was associated only with decreased ICU readmission (OR 0.23 [95\% CI 0.07 to 0.79]; $\mathrm{P}=0.02$ ).

CONCLUSIONS: Obesity was not necessarily associated with worse outcomes in critically ill patients.

Key Words: Critical care; Obesity; Outcomes

$\mathrm{T}$ he prevalence of obesity is rapidly rising in Canada and other industrialized nations. More than $60 \%$ of adult Canadians are classified as overweight (body mass index $[\mathrm{BMI}] \geq 25 \mathrm{~kg} / \mathrm{m}^{2}$ ) and one-quarter are obese (BMI $\geq 30 \mathrm{~kg} / \mathrm{m}^{2}$ ), which represents a doubling since 1981 (1). In the United States, prevalence rates for obesity are even higher, with approximately one-third of the adult population being obese.

Outpatient data have generally indicated that BMI $\geq 30 \mathrm{~kg} / \mathrm{m}^{2}$ is a predictor of increased mortality (2-4), although this finding may be predominantly influenced by individuals with moderately severe and severe obesity (5). The impact of obesity (BMI $\geq 30 \mathrm{~kg} / \mathrm{m}^{2}$ ) on inpatients, and particularly critically ill patients, is much less clear, with studies reporting conflicting results on important outcomes (6-16). A recent meta-analysis involving $>20,000$ patients found no evidence of increased mortality (17), but markers of morbidity, including length of intubation and intensive care unit (ICU) length of stay (LOS), were both increased in the obese patients. Most studies in this area have been limited by either their retrospective design or small sample size.

There are several possible limitations to the use of BMI, both as a marker of adiposity and as a prognostic marker for ICU outcomes, because it does not distinguish patients with different body composition

\section{L'association entre l'obésité et l'issue des patients gravement malades}

HISTORIQUE : Le taux d'obésité augmente dans le monde, particulièrement en Amérique du Nord. On connaît mal les répercussions de l'obésité sur l'issue des patients gravement malades.

MÉTHODOLOGIE : Les chercheurs ont mené une étude d'observation prospective auprès d'une cohorte de patients consécutifs admis dans une unité tertiaire de soins intensifs au Canada entre le 10 janvier 2008 et le 31 mars 2009. Étaient exclus les patients de moins de 18 ans, admis moins de 24 heures, subissant une opération cardiaque planifiée ou présentant une grossesse, une ascite marquée, un abdomen chirurgical ouvert ou une mort cérébrale à l'admission. La taille, le poids et le tour de taille étaient mesurés au moment de l'admission à l'unité de soins intensifs (USI). Les coparamètres primaires étaient la mortalité à l'USI et un composite de mortalité à l'USI, de réintubation, de pneumonie associée à la ventilation, de sepsis du cathéter et de réadmission à l'USI. Les sujets étaient stratifiés entre les obèses et les non-obèses, selon deux mesures distinctes : indice de masse corporelle (IMC) d'au moins $30 \mathrm{~kg} / \mathrm{m}^{2}$ et nouvelle mesure du ratio entre le tour de taille et la taille (TTT) au $75^{\mathrm{e}}$ percentile.

RÉSULTATS : Chez les 449 sujets dont l'IMC était d'au moins $18,5 \mathrm{~kg} / \mathrm{m}^{2}$, l'IMC et la TTT de $348(77,5 \%)$ d'entre eux étaient disponibles pour l'analyse comparative. Aucune des mesures d'obésité ne s'associait aux paramètres primaires. Le groupe ayant un IMC d'au moins $30 \mathrm{~kg} / \mathrm{m}^{2}$ présentait un risque plus faible de mortalité au bout de six mois que le groupe dont l'IMC était inférieur à $30 \mathrm{~kg} / \mathrm{m}^{2}$ (RC rajusté 0,59 [95\% IC $0,36$ à 0,97$] ; \mathrm{P}=0,04$ ), mais qui était intubé plus longtemps ( $\mathrm{RR}$ rajusté 1,56 [95 \% IC 1,17 à 2,07]; $\mathrm{P}=0,003$ ) et une hospitalisation plus longue à l'USI (RR rajusté 1,67 [95 \% IC 1,21 à 2,31]; $\mathrm{P}=0,002$ ). Par contre, une mesure du TTT au $75^{\mathrm{e}}$ percentile s'associait seulement à une diminution des admissions à l'USI (RC 0,23 [95 \% IC 0,07 à 0,79]; P=0,02).

CONCLUSIONS : L'obésité ne s'associait pas nécessairement à une issue plus néfaste chez les patients gravement malades.

or degrees of edema. Abdominal obesity may be a more relevant issue than BMI, and several population-based studies have demonstrated abdominal obesity to be a powerful predictor of mortality even after correction for BMI $(16,18,19)$. However, there has been very little research investigating whether abdominal adiposity is a better predictor of outcomes compared with BMI in critically ill patients. Interestingly, however, a recent study by Paolini et al (20) reported sagittal abdominal diameter to be a useful predictor of mortality in the ICU.

For the present study, we prospectively evaluated the predictive value of both BMI as well as the waist-to-height ratio (WHR) for ICU mortality and morbidity. WHR has been reported in outpatients as an effective way of predicting cardiovascular morbidity $(21,22)$ and reflects body morphology more so than BMI. Due to the simplicity of the WHR, we believed it would be optimal to apply to our ICU patient population.

\section{METHODS}

Patients admitted to the Royal University Hospital (Saskatoon, Saskatchewan) ICU - a tertiary referral, mixed medical-surgical, trauma and cardiovascular surgery ICU between January 10, 2008

${ }^{1}$ Department of Medicine; ${ }^{2}$ Clinical Research Support Unit; College of Medicine, University of Saskatchewan, Saskatoon, Saskatchewan

Correspondence: Dr John K Reid, Division of Respiratory, Critical Care and Sleep Medicine, 5th Floor, Ellis Hall, 103 Hospital Drive, Saskatoon,

Saskatchewan S7N OW8. Telephone 250-995-0211, fax 250-995-1443, e-mail j.reid@usask.ca 
TABLE 1

Comparison of baseline variables

\begin{tabular}{|c|c|c|c|c|c|c|c|c|}
\hline \multirow{2}{*}{ Variable } & & \multirow{2}{*}{$\begin{array}{c}\text { All subjects } \\
\text { combined } \\
(n=348)\end{array}$} & \multicolumn{2}{|c|}{ Stratified by BMI status } & \multirow[b]{2}{*}{$\mathbf{P}^{*}$} & \multicolumn{2}{|c|}{ Stratified by WHR status } & \multirow[b]{2}{*}{$\mathbf{P}^{*}$} \\
\hline & & & $\begin{array}{c}\text { Nonobese, } \\
n=202\end{array}$ & Obese, $n=146$ & & $\begin{array}{c}\text { Nonobese, } \\
n=258\end{array}$ & Obese, $n=90$ & \\
\hline \multicolumn{2}{|c|}{$\overline{\text { Age, years, mean } \pm S D}$} & $54.3 \pm 18.1$ & $51.8 \pm 18.9$ & $57.7 \pm 16.4$ & 0.003 & $52.2 \pm 18.4$ & $60.3 \pm 15.9$ & 0.0002 \\
\hline \multicolumn{2}{|l|}{ Male } & $216(62.1)$ & $132(65.3)$ & $84(57.5)$ & 0.14 & $171(69.0)$ & $38(42.2)$ & $<0.0001$ \\
\hline \multicolumn{2}{|l|}{ Female } & $132(37.9)$ & $70(34.7)$ & $62(42.5)$ & & $80(31.0)$ & $52(57.8)$ & \\
\hline \multicolumn{2}{|c|}{ APACHE II score, mean \pm SD } & $21.9 \pm 8.4$ & $20.8 \pm 8.5$ & $23.5 \pm 8.1$ & 0.02 & $21.0 \pm 8.3$ & $24.1 \pm 8.3$ & 0.02 \\
\hline \multirow[t]{2}{*}{ Cardiac failure } & Yes & $11(4.6)$ & $2(1.5)$ & $9(8.7)$ & $0.01^{\dagger}$ & $2(1.20$ & $9(13.4)$ & $0.0002^{\dagger}$ \\
\hline & No & $228(95.4)$ & $134(98.5)$ & $94(91.3)$ & & $170(98.8)$ & $58(86.6)$ & \\
\hline \multirow{2}{*}{$\begin{array}{l}\text { Respiratory } \\
\text { failure }\end{array}$} & Yes & $17(7.1)$ & $8(5.8)$ & $9(8.7)$ & 0.39 & $7(4.0)$ & $10(14.9)$ & $0.009^{\dagger}$ \\
\hline & No & $223(92.9)$ & $129(94.2)$ & $94(91.3)$ & & $166(96.0)$ & $57(85.1)$ & \\
\hline \multirow[t]{2}{*}{ Renal failure } & Yes & $17(7.1)$ & $8(5.8)$ & $9(8.7)$ & 0.39 & $8(4.6)$ & $9(13.4)$ & $0.02^{\dagger}$ \\
\hline & No & $223(92.9)$ & $129(94.2)$ & $94(91.3)$ & & $165(95.4)$ & $58(86.6)$ & \\
\hline \multicolumn{9}{|c|}{ Admission diagnosis } \\
\hline \multicolumn{2}{|l|}{ Medical } & $166(48.4)$ & $90(45.5)$ & $76(52.4)$ & $0.03^{\ddagger}$ & $113(44.7)$ & $53(58.9)$ & $0.01^{\ddagger}$ \\
\hline \multicolumn{2}{|l|}{ Surgical } & $88(25.7)$ & $46(23.2)$ & $42(29.0)$ & & $64(25.3)$ & $24(26.7)$ & \\
\hline \multicolumn{2}{|l|}{ Trauma } & $89(25.9)$ & $62(31.3)$ & $27(18.6)$ & & $76(30.0)$ & $13(14.4)$ & \\
\hline \multicolumn{2}{|l|}{ BMI, mean \pm SD } & $29.8 \pm 7.0$ & $25.1 \pm 2.9$ & $36.3 \pm 5.8$ & & $26.9 \pm 4.4$ & $38.0 \pm 6.7$ & \\
\hline \multicolumn{2}{|l|}{ WHR, mean \pm SD } & $0.61 \pm 0.12$ & $0.54 \pm 0.07$ & $0.71 \pm 0.10$ & & $0.56 \pm 0.07$ & $0.77 \pm 0.09$ & \\
\hline
\end{tabular}

Data presented as $n$ (\%) unless otherwise specified. Body mass index (BMI): nonobese $18.5 \mathrm{~kg} / \mathrm{m}^{2}$ to $29.9 \mathrm{~kg} / \mathrm{m}^{2}$; obese $\geq 30 \mathrm{~kg} / \mathrm{m}^{2}$; Waist-to-height ratio (WHR): nonobese $\leq 75$ th percentile; obese $>75$ th percentile. *Nonobese vs obese; ${ }^{\dagger}$ Based on Fisher's exact test due to small expected cell sizes; $¥$ Pairwise comparison BMI: medical versus surgical $=0.77$, surgical versus trauma $=0.02$, medical versus trauma $=0.02 ;$ WHR: medical versus surgical $=0.44$, surgical versus trauma $=0.04$, medical versus trauma $=0.003$. Continuous variables compared by two-sided, two-sample t test; categorical proportions compared by $\chi^{2}$ test with exceptions for Fisher's exact as noted. Cell counts within categorical variables may not sum to $n$ due to missing values. APACHE Acute Physiology and Chronic Health Evaluation

and March 31, 2009, were prospectively evaluated. It is a 14-bed, 'closed' unit run by an intensivist-led, multidisciplinary team. University and health region ethics approval was obtained. Exclusion criteria were age $<18$ years, ICU stay $<24 \mathrm{~h}$, brain death on arrival to ICU, pregnancy, admission for possible organ donation, postoperative management of elective cardiovascular surgery, or the presence of either an unclosed surgical abdomen or significant ascites. Additionally, data from subjects with a BMI $<18.5 \mathrm{~kg} / \mathrm{m}^{2}$ were recorded but excluded from any comparative analysis because of concern that they may have a higher burden of chronic illness and consequent predisposition toward the complications under study (15). Only the first ICU admission for any given patient during the study period was evaluated. Only subjects with both BMI and WHR data were analyzed.

On admission to the ICU, height, weight and waist circumference were measured by the ICU staff. The bedside nurse measured waist circumference at the level of the umbilicus with patients supine. Nurses were educated in the appropriate technique, and a set of written instructions with an appropriate diagram was kept available in the ICU at all times. Height was routinely measured on admission by the respiratory therapists becasue it is used in the calculation of target minute ventilation. At time of admission, baseline data collected included basic demographic data, admitting diagnosis, reason for requiring ICU admission, Acute Physiology and Chronic Health Evaluation (APACHE) II score and important comorbidities, as defined by APACHE II criteria (23). This information is routinely collected at bedside rounds and later verified by a specialty-trained nurse as part of the health region's continuous quality assurance program.

Each patient underwent two different methods for assessment of obesity. First, BMI was calculated using the patient's admission weight in kilograms divided by their height in meters squared. The WHR was calculated using waist circumference $(\mathrm{cm})$ and height $(\mathrm{cm})$ measured at ICU admission. An increased WHR was defined as $>75$ th percentile (WHR75) for the study population. All outcomes were analyzed separately according to BMI and WHR; obese (BMI $\left.\geq 30 \mathrm{~kg} / \mathrm{m}^{2}\right)$ versus nonobese (BMI $18.5 \mathrm{~kg} / \mathrm{m}^{2}$ to $<30 \mathrm{~kg} / \mathrm{m}^{2}$ ), and WHR75 versus WHR $<75$ th percentile. Subjects were followed until death or six months post-ICU admission. Two predetermined end points were evaluated: ICU mortality; and a composite of ICU mortality, reintubation, ventilator-associated pneumonia, line sepsis and ICU readmission as coprimary end points. The individual components of this composite outcome, as well as six-month mortality, were analyzed as a priori secondary outcomes.

\section{Statistics}

The majority of the statistical analysis was performed using SPSS version 20 (IBM Corporation, USA) for Windows (Microsoft Corporation, USA). Among included patients (those with both BMI and WHR data), basic descriptive characteristics were compared according to obesity status using $t$ tests for continuous variables and $\chi^{2}$ or Fisher's exact testing for categorical variables. Additionally, included patients were compared as a single group against those excluded from analysis due to missing obesity metrics. Crude associations between obesity and categorical outcome variables were assessed using $\chi^{2}$ testing or Fisher's exact test. The noncategorical outcomes of LOS and length of intubation were examined as the number of completed days; due to the overdispersed count nature of these outcomes, univariate negative binomial models were used for analysis. The zero-truncated form of the model was required for assessment of the LOS outcome because all stays were at least one full day according to the inclusion criteria; this specific model type was generated using the NL Mixed procedure provided by SAS version 9.3 (SAS Institute Inc, USA). Multivariable forms of logistic and negative binomial regression were also undertaken 


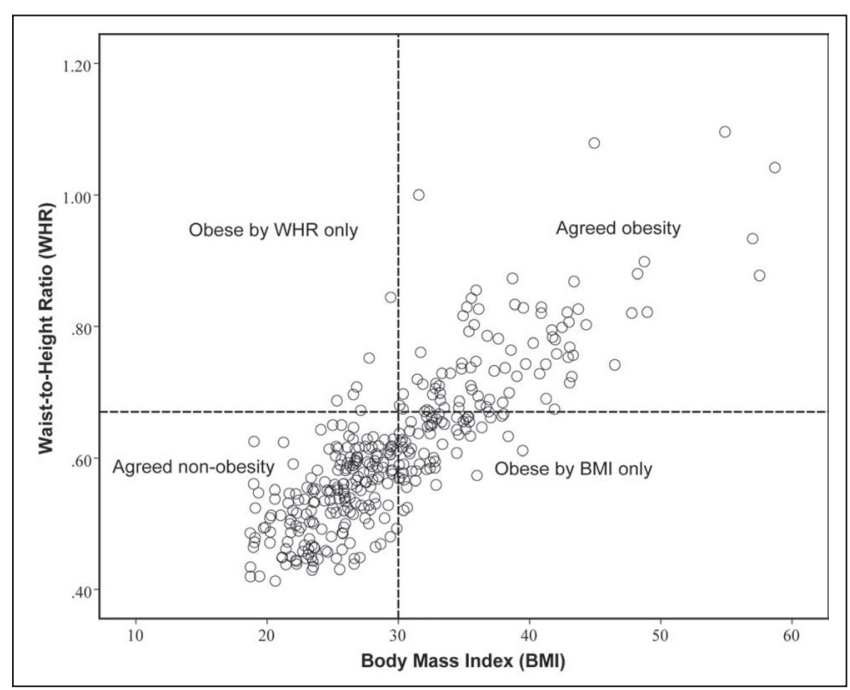

Figure 1) Classification of obesity according to body mass index (BMI) $\geq 30 \mathrm{~kg} / \mathrm{m}^{2}$ versus the 75 th percentile of waist-to-height ratio (WHR75). The figure shows that there was a substantial portion of patients who were classified as obese according to BMI, but not by WHR75. Conversely, there were very few patients who were categorized as obese according to WHR75 but not confirmed by BMI $\geq 30 \mathrm{~kg} / \mathrm{m}^{2}$. Obese by WHR only, $n=6(1.7 \%)$; agreed obesity by both WHR and BMI, $n=84$ (24.1\%); obese by BMI only, $n=62(17.8 \%)$; agreed nonobesity by both WHR and BMI, $n=196$ (56.3\%)

in an attempt to isolate the relationship of obesity and the specific outcomes apart from associated potential confounders. Prespecified $\mathrm{P}<0.05$ was considered to be statistically significant and all means are expressed with SDs.

\section{RESULTS}

There were 463 patients who met the study entry criteria between January 10, 2008 and March 31, 2009. Twelve subjects were excluded due to BMI values $<18.5 \mathrm{~kg} / \mathrm{m}^{2}$. In addition, one subject was excluded from the data for an extreme LOS (204 completed days), this value lying $15.0 \mathrm{SDs}$ from the mean and far beyond the second longest LOS of 63 days. A second subject was excluded because the primary purpose of ICU admission was for palliation.

Among the remaining 449 subjects, both BMI and WHR were available for evaluation in $348(77.5 \%)$. Men comprised $216(62.1 \%)$, the mean $( \pm \mathrm{SD})$ patient age was $54.3 \pm 18.1$ years and mean APACHE II score was $21.9 \pm 8.4$. The mean BMI was $29.8 \pm 7.0 \mathrm{~kg} / \mathrm{m}^{2}$. The cut-off for the WHR75 was a ratio of $>0.67$. The cross-classification of subject on both obesity metrics (Figure 1 ) indicated that a substantial number of patients in the BMI $\geq 30 \mathrm{~kg} / \mathrm{m}^{2}$ group were not obese according to WHR75, and that very few who were obese by WHR75 did not have a BMI $\geq 30 \mathrm{~kg} / \mathrm{m}^{2}$; suggesting that the WHR75 subjects were essentially a subgroup of the BMI $\geq 30 \mathrm{~kg} / \mathrm{m}^{2}$ subjects. Baseline characteristics of included subjects, combined and stratified according to their respective BMI and WHR obesity status, are presented in Table 1. Obese subjects were older and had higher APACHE II scores, more frequently experienced cardiac failure and were less likely to have had a traumatic admission than nonobese subjects, regardless of whether they were categorized according to BMI $\geq 30 \mathrm{~kg} / \mathrm{m}^{2}$ or WHR (Table 1). Based on the available data, a significant difference between study subjects and those excluded due to missing obesity metrics could not be determined (Table 2).

\section{Composite end point}

The a priori primary composite end point of ICU mortality, reintubation, ventilator-associated pneumonia, line sepsis and ICU readmission occurred in $41.7 \%$ of the entire cohort of 348 patients. Obesity,
TABLE 2

Comparison of included and excluded* subjects

\begin{tabular}{|c|c|c|c|}
\hline & $\begin{array}{l}\text { Subjects with both } \\
\text { measures present } \\
(n=348)\end{array}$ & $\begin{array}{l}\text { All excluded } \\
\text { subjects } \\
(n=101)\end{array}$ & $\mathbf{P}^{\dagger}$ \\
\hline Age, years, mean \pm SD & $54.3 \pm 18.1$ & $55.3 \pm 18.2$ & 0.63 \\
\hline \multicolumn{4}{|l|}{ Sex } \\
\hline Male & $216(62.1)$ & $65(64.4)$ & 0.68 \\
\hline Female & $132(37.9)$ & $36(35.6)$ & \\
\hline APACHE II score, mean \pm SD & $21.9 \pm 8.4$ & $20.8 \pm 7.8$ & 0.41 \\
\hline Unknown, n (\% of group) & $101(40.5)$ & $43(43.6)$ & \\
\hline \multicolumn{4}{|l|}{ Comorbidities } \\
\hline \multicolumn{4}{|l|}{ Cardiac failure } \\
\hline Yes & $11(4.6)$ & $3(6.3)$ & $0.71^{\ddagger}$ \\
\hline No & $228(95.4)$ & $45(93.8)$ & \\
\hline Unknown, $\mathrm{n}$ (\% of group) & $109(31.3)$ & $53(52.5)$ & \\
\hline \multicolumn{4}{|l|}{ Respiratory failure } \\
\hline Yes & $17(7.1)$ & $3(6.3)$ & $1.0^{\ddagger}$ \\
\hline No & $223(92.9)$ & $45(93.8)$ & \\
\hline Unknown, $\mathrm{n}$ (\% of group) & $108(31.0)$ & $53(52.5)$ & \\
\hline \multicolumn{4}{|l|}{ Renal failure } \\
\hline Yes & $17(7.1)$ & $6(12.5)$ & $0.24^{\ddagger}$ \\
\hline No & $223(92.9)$ & $42(87.5)$ & \\
\hline Unknown, $\mathrm{n}$ (\% of group) & $108(31.0)$ & $53(52.5)$ & \\
\hline \multicolumn{4}{|l|}{ Hepatic failure } \\
\hline Yes & $9(3.8)$ & $1(2.1)$ & $1.0^{\ddagger}$ \\
\hline No & $230(96.2)$ & $47(97.2)$ & \\
\hline Unknown, $\mathrm{n}$ (\% of group) & $109(31.3)$ & $53(52.5)$ & \\
\hline \multicolumn{4}{|l|}{ Immunocompromised } \\
\hline Yes & $14(5.9)$ & $2(4.3)$ & $1.0^{\ddagger}$ \\
\hline No & $224(94.1)$ & $44(95.7)$ & \\
\hline Unknown, $\mathrm{n}$ (\% of group) & $110(31.6)$ & $55(54.4)$ & \\
\hline \multicolumn{4}{|l|}{ Admission diagnosis } \\
\hline Medical & $166(48.4)$ & $43(57.3)$ & 0.35 \\
\hline Surgical & $88(25.7)$ & $17(22.7)$ & \\
\hline Trauma & 89 (25.9) & $15(20.0)$ & \\
\hline Unknown, $\mathrm{n}$ (\% of group) & $5(1.4)$ & $26(25.0)$ & \\
\hline
\end{tabular}

Data presented as $n(\%)$ unless otherwise specified. *Excluded due to missing values for one or both obesity measurements; ${ }^{\dagger}$ Comparison of the characteristics of included and excluded groups where characteristics available; FFisher's exact test used due to small expected cell sizes. APACHE Acute Physiology and Chronic Health Evaluation

defined as BMI $\geq 30 \mathrm{~kg} / \mathrm{m}^{2}$, was not associated with an increased frequency of the composite primary end point compared with the nonobese group $(41.1 \%$ versus $42.1 \%)$. Similarly, for the WHR75 group, there was also no difference in the primary composite end point $(42.2 \%$ versus $41.5 \%)$. Univariate analysis revealed that the only associations with the primary composite end point were the expected risk factors of APACHE II score at admission $(\mathrm{P}<0.0001)$ and immunocompromised state $(\mathrm{P}=0.04)$; an additional borderline significant risk was also noted for female sex $(P=0.07)$. Given that inclusion of comorbidities and APACHE scores would result in the exclusion of a substantial proportion of subjects due to missing data (Table 2), together with the potential for bias of the estimates on adjustment, only sex, age and admission type were adjusted for. These three covariates were retained for consistency across all outcomes modelled. Adjustment for these covariates did not lead to a meaningful change in results (Table 3 ).

\section{ICU mortality}

No difference in ICU mortality rate was detected for obese patients, regardless of whether measured as $\mathrm{BMI} \geq 30 \mathrm{~kg} / \mathrm{m}^{2}$ (17.8\% versus $19.3 \% ; \mathrm{P}=0.72$ ) or WHR75 (22.2\% versus $17.4 \% ; \mathrm{P}=0.32$ ) (Table 3 ). 
TABLE 3

Frequencies/mean values and univariate associations of outcomes in relation to obesity status, assessed by body mass index (BMI) and waist-to-height ratio (WHR), respectively

\begin{tabular}{|c|c|c|c|c|c|c|c|c|c|c|c|c|}
\hline & & \multirow[b]{2}{*}{$\begin{array}{l}\text { All subjects } \\
\text { combined }\end{array}$} & \multicolumn{2}{|c|}{$\begin{array}{c}\text { Stratified according to } \\
\text { BMI status }\end{array}$} & \multirow[b]{2}{*}{$\mathbf{P}^{*}$} & \multirow[b]{2}{*}{$\mathrm{OR}^{\dagger}$} & \multirow[b]{2}{*}{$95 \% \mathrm{Cl}$} & \multicolumn{2}{|c|}{$\begin{array}{c}\text { Stratified according to } \\
\text { WHR status }\end{array}$} & \multirow[b]{2}{*}{$\mathbf{P}^{*}$} & \multirow[b]{2}{*}{$\mathrm{OR}^{\dagger}$} & \multirow[b]{2}{*}{$95 \% \mathrm{Cl}$} \\
\hline & & & $\begin{array}{l}\text { Nonobese } \\
(n=202)\end{array}$ & $\begin{array}{l}\text { Obese } \\
(n=146)\end{array}$ & & & & $\begin{array}{l}\text { Nonobese } \\
(n=258)\end{array}$ & $\begin{array}{l}\text { Obese } \\
(n=90)\end{array}$ & & & \\
\hline \multirow[t]{2}{*}{ Composite } & Yes & $145(41.7)$ & $85(42.1)$ & $60(41.1)$ & 0.85 & 0.96 & $0.62-1.48$ & $107(41.5)$ & $38(42.2)$ & 0.90 & 1.03 & $0.63-1.68$ \\
\hline & No & $203(58.3)$ & 117 (57.9) & $86(58.9)$ & & & & $151(58.5)$ & $52(57.8)$ & & & \\
\hline $\begin{array}{l}\text { ICU } \\
\text { mortality }\end{array}$ & Yes & 65 (18.7) & 39 (19.3) & $26(17.8)$ & 0.72 & 0.91 & $0.52-1.57$ & $45(17.4)$ & $20(22.2)$ & 0.32 & 1.35 & $0.75-2.44$ \\
\hline \multicolumn{2}{|c|}{ Reintubation Yes } & 44 (12.6) & $23(11.4)$ & $21(14.4)$ & 0.41 & 1.31 & $0.69-2.47$ & 28 (10.9) & $16(17.8)$ & 0.09 & 1.78 & $0.91-3.46$ \\
\hline & No & $304(87.4)$ & 179 (88.6) & $125(85.6)$ & & & & $230(89.1)$ & $74(82.2)$ & & & \\
\hline \multirow[t]{2}{*}{ VAP } & Yes & 35 (16.1) & $24(18.0)$ & $11(13,1)$ & 0.33 & 0.68 & $0.32-1.48$ & $29(17.4)$ & $6(12.0)$ & 0.37 & 0.65 & $0.25-1.67$ \\
\hline & No & $182(83.9)$ & $109(82.0)$ & 73 (86.9) & & & & $138(82.6)$ & $44(88.0)$ & & & \\
\hline \multirow[t]{2}{*}{ Line sepsis } & Yes & $4(1.1)$ & $2(1.0)$ & $2(1.4)$ & $1.0^{\ddagger}$ & 1.39 & $0.19-9.98$ & $2(0.8)$ & $2(2.2)$ & $0.28^{\ddagger}$ & 2.91 & $0.40-21.00$ \\
\hline & No & 344 (98.9) & $200(99.0)$ & $144(98.6)$ & & & & $256(99.2)$ & 88 (97.8) & & & \\
\hline $\begin{array}{r}\text { Six-month } \\
\text { mortality }\end{array}$ & No & 228 (65.5) & $130(64.4)$ & $98(67.1)$ & & & & $171(66.3)$ & $57(63.3)$ & & & \\
\hline \multicolumn{13}{|c|}{ Continuous outcomes } \\
\hline \multicolumn{2}{|c|}{$\begin{array}{l}\text { ICU LOS, com- } \\
\text { pleted days, } \\
\text { mean } \pm \text { SD }\end{array}$} & $7.4 \pm 9.1$ & $6.0 \pm 6.2$ & $9.3 \pm 11.7$ & \multicolumn{2}{|c|}{$\begin{array}{r}0.001 \S \mathrm{RR}: \\
1.72^{\S}\end{array}$} & $1.24-2.37 \S$ & $6.8 \pm 8.0$ & $9.0 \pm 11.4$ & $0.15^{\S}$ & $\begin{array}{l}\text { RR: } \\
\quad 1.41 \S\end{array}$ & $0.97-2.05^{\S}$ \\
\hline \multicolumn{2}{|c|}{$\begin{array}{l}\text { Length of } \\
\text { intubation, } \\
\text { completed days, } \\
\text { mean } \pm \text { SD }\end{array}$} & $5.1 \pm 7.1$ & $4.1 \pm 5.5$ & $6.5 \pm 8.8$ & $0.002^{\pi}$ & $\begin{array}{l}\text { RR: } \\
1.57 \pi\end{array}$ & $1.19-2.08 \pi$ & $4.8 \pm 6.7$ & $6.2 \pm 8.2$ & $0.10^{\pi}$ & $\begin{array}{l}\text { RR: } \\
\quad 1.31 \pi\end{array}$ & $0.95-1.81 \pi$ \\
\hline
\end{tabular}

Furthermore, there was no difference in unadjusted six-month mortality when stratified according to BMI $\geq 30.0 \mathrm{~kg} / \mathrm{m}^{2}(32.9 \%$ versus $35.6 \% ; \mathrm{P}=0.59)$. Adjustment for the specified covariates, however, did result in a significant association between $\mathrm{BMI} \geq 30 \mathrm{~kg} / \mathrm{m}^{2}$ and a reduction in risk of six-month mortality (OR 0.59 [95\% CI 0.36 to 0.97]; $\mathrm{P}=0.04$ ) (Table 4). This adjusted estimate for WHR75 was also in the protective direction but did not achieve statistical significance (OR 0.62 [ $95 \%$ CI 0.35 to 1.10 ]; $\mathrm{P}=0.10$ ) (Table 4).

\section{Morbidities}

The mean LOS for the entire population was $7.4 \pm 9.1$ days. Patients with $\mathrm{BMI} \geq 30 \mathrm{~kg} / \mathrm{m}^{2}$ stayed a mean of 3.3 days longer than controls (RR 1.72 [95\% CI 1.24 to 2.37]; $\mathrm{P}=0.001$ ) (Table 3). When stratified according to WHR75, there was a mean increase in ICU LOS of 2.2 days for the obese patients, but this did not achieve significance (Table 3 ). BMI $\geq 30 \mathrm{~kg} / \mathrm{m}^{2}$ was also associated with a longer length of intubation, increasing on average by 2.4 days, an association again remaining after adjustment for age, sex and diagnosis (RR 1.56 [95\% CI 1.17 to 2.07]; $\mathrm{P}=0.003$ ). This association was not observed in the WHR comparison.

Interestingly, both metrics of obesity were associated with a lower rate of ICU readmission (Table 4), a finding that reached statistical significance for the WHR75 group (OR 0.23 [95\% CI 0.07 to 0.79]; $\mathrm{P}=0.02$ ). The difference in proportions of WHR obese and nonobese subjects requiring readmission, initially $3.3 \%$ versus $11.2 \%$, did not substantially change when subjects who died during the initial ICU admission or were known to be immunocompromised (4.3\% versus $12.6 \%)$ were excluded.

\section{DISCUSSION}

The influence of obesity on important patient-related ICU outcomes is uncertain. Although the literature has been divided on this issue, the weight of contemporary evidence suggests that obesity (defined as BMI $\geq 30 \mathrm{~kg} / \mathrm{m}^{2}$ ) is not associated with increased ICU mortality $(15,17,25)$. Our analysis was one of the largest prospective studies in this area and one of the few to simultaneously investigate more than one measure of obesity. Our results support the concept that while obesity may be associated with longer time of intubation and ICU stay (outcomes that are inherently linked), obesity alone is not predictive of increased mortality or adverse outcomes in the ICU.

Our findings are particularly interesting because the obese subgroups had higher acuity of illness scores at the time of ICU admission (Table 1). One potential explanation for studies that have shown neutral to beneficial effect of obesity on ICU outcomes is that none of the commonly used illness severity scores (eg, APACHE II) have been validated in obese patients or even account for obesity (26). It may be that obesity complicates the appropriate assessment of many physiological factors used in mortality predictions, such as creatinine clearance, oxygenation, respiratory rate and serum electrolytes, among others. When assessing the effect of obesity on critical care outcomes, correcting for severity of illness score could then lead to the obese subgroup being inappropriately compared with nonobese patients, who are, in fact, more acutely ill. This may have been a factor in our study. We also recognize that some of the comorbidities were more prevalent among obese subjects (Table 1) and may have contributed to the increased acuity of their illness. We did not control for them in the 
TABLE 4

Multivariable logistic/negative binomial regression models*

\begin{tabular}{|c|c|c|c|c|c|c|}
\hline \multirow[b]{2}{*}{ Categorical outcomes } & \multicolumn{2}{|c|}{ BMI (obese versus nonobese) } & \multirow[b]{2}{*}{$\mathbf{P}$} & \multicolumn{2}{|c|}{ WHR (obese versus nonobese) } & \multirow[b]{2}{*}{$\mathbf{P}$} \\
\hline & Estimate \pm SE & OR $(95 \% \mathrm{Cl})$ & & Estimate \pm SE & OR $(95 \% \mathrm{Cl})$ & \\
\hline Composite end point & $-0.17 \pm 0.23$ & $0.84(0.54-1.32)$ & 0.46 & $-0.21 \pm 0.26$ & $0.81(0.49-1.37)$ & 0.44 \\
\hline Intensive care unit mortality & $-0.40 \pm 0.30$ & $0.67(0.38-1.20)$ & 0.18 & $-0.14 \pm 0.32$ & $0.87(0.46-1.64)$ & 0.66 \\
\hline Ventilator-associated pneumonia & $-0.21 \pm 0.41$ & $0.81(0.36-1.83)$ & 0.61 & $-0.26 \pm 0.52$ & $0.77(0.28-2.15)$ & 0.62 \\
\hline Intensive care unit readmission & $-0.72 \pm 0.41$ & $0.49(0.22-1.08)$ & 0.08 & $-1.48 \pm 0.63$ & $0.23(0.07-0.79)$ & 0.02 \\
\hline Six-month mortality & $-0.53 \pm 0.26$ & $0.59(0.36-0.97)$ & 0.04 & $-0.47 \pm 0.29$ & $0.62(0.35-1.10)$ & 0.10 \\
\hline Intensive care unit LOS, completed days $^{\dagger}$ & $0.51 \pm 0.17$ & $1.67(1.21-2.31)$ & 0.002 & $0.29 \pm 0.20$ & $1.33(0.90-1.98)$ & 0.15 \\
\hline Length of intubation, completed days & $0.44 \pm 0.15$ & $1.56(1.17-2.07)$ & 0.003 & $0.22 \pm 0.18$ & $1.25(0.88-1.76)$ & 0.21 \\
\hline
\end{tabular}

${ }^{*}$ All models adjusted for age (<40 years, 40 to 69 years and $\geq 70$ years), sex and diagnosis type (medical, surgical, trauma); $†$ Zero truncated negative binomial model used for length of stay (LOS) because inclusion criteria required a minimum $24 \mathrm{~h}$ admission. Full model parameters are available for each outcome in Appendix A. BMI Body mass index (obese $\geq 30 \mathrm{~kg} / \mathrm{m}^{2}$; nonobese $18.5 \mathrm{~kg} / \mathrm{m}^{2}$ to $29.9 \mathrm{~kg} / \mathrm{m}^{2}$ ); RR Rate ratio; WHR Waist-to-height ratio (obese >75th percentile; nonobese $\leq 75$ th percentile)

models, however, in part due to their potential role as intermediary factors through which obesity may have its effect.

In our study, we found a longer mean ICU LOS for BMI $\geq 30 \mathrm{~kg} / \mathrm{m}^{2}$ subjects compared with their nonobese counterparts (3.3 days difference, adjusted RR 1.67 [95\% CI 1.21 to 2.31]; $\mathrm{P}=0.002$ ). The association between obesity and prolonged LOS is an interesting, but again inconsistent, finding in the literature $(6,7,16,25,27-29)$. Lengths of intubation and ICU LOS are intuitively linked outcomes; not surprisingly, they were closely related in our study population. It may be that obese patients have longer ICU LOS due to difficult weaning as a result of obesity's deleterious effect on respiratory mechanics and ventilation-perfusion matching. It is also possible that the expectation of more complicated care in obese patients - including airway management, vascular access mobility and glucose control, among others may have influenced physician and health care team decisions to keep obese patients in the controlled ICU environment longer than nonobese patients. As such, clinician judgment/bias could be an important factor influencing the lengths of intubation and ICU stay for obese patients.

BMI is the most commonly used measure for obesity because of its simplicity, but it does not assess body composition and, therefore, has inherent limitation as a benchmark for 'obesity'. The question of body composition is particularly relevant for critically ill patients, in whom aggressive fluid resuscitation could elevate the BMI and thereby misclassify some sicker patients as 'obese' (30). Additionally, chronically ill patients often experience substantial muscle wasting, which may result in an artificially low BMI among patients who actually have a relatively high ratio of adipose tissue to lean muscle mass. Finally, we know from outpatient studies that abdominal obesity is actually a better predictor of mortality than BMI (18-20), and recent work by Paolini et al (20) suggests that this is also the case in critically ill patients.

The traditional measure of abdominal obesity - the waist-to-hip ratio - has been described for awake, upright patients. We were concerned that this value may not translate well to supine, often comatose, critically ill patients. Because the waist-to-height ratio (WHR) has been reported as an alternative useful assessment of abdominal obesity $(21,22)$, and height was already routinely measured by our respiratory therapy staff, the WHR required our nurses to take only one additional measurement at the level of the umbilicus. Additionally, because height values are almost always relatively larger than those for the hip, small measurement errors would have less influence on the WHR than the waist-to-hip measure. We believed, therefore, that the WHR was a simpler, probably more reproducible and likely more sanitary measure than waist to hip. While the WHR75 used in our study involved a different technique than that of Paolini et al (20), it was drawn from the same concept and had the advantage of being a simple bedside measurement that is easy to perform at no cost. The WHR75 did prove to be thought provoking in that it identified a subgroup of BMI $\geq 30 \mathrm{~kg} / \mathrm{m}^{2}$ subjects (Figure 1), with somewhat different results on our outcomes of interest, but the overall signal remained that obesity defined by either metric was not associated with increased ICU mortality or important morbidity.

An important limitation to our study was the fact that we did not have complete data on all 449 eligible subjects. Despite this weakness, our study still describes one of the largest prospectively collected cohorts in this field and we believe it makes a valuable contribution to the understanding of obesity's interaction with critical illness.

\section{CONCLUSION}

In our prospective, observational study, we found that WHR75 proved to be a slightly more stringent criteria for obesity (Figure 1) than the conventional BMI $\geq 30 \mathrm{~kg} / \mathrm{m}^{2}$, with slightly different outcomes. Neither metric was associated with either of our primary end points of ICU mortality or the composite of ICU mortality, ventilatorassociated pneumonia, line sepsis, ICU readmission and reintubation. The relationship between obesity and ICU outcomes is clearly complex and requires study in large, prospective trials before a definitive conclusion can be drawn. Measurements that assess body morphology provide a complementary assessment to BMI and, therefore, result in slightly different patient categorization. Therefore, we suggest that such metrics be considered in the design of future trials.

ACKNOWLEDGEMENTS: The authors thank the nursing and respiratory therapy staff of Royal University Hospital for assisting in data collection.

AUTHOR CONTRIBUTIONS: Study design and data collection: SW, AW and JR; data analysis: RB, SW, AW and JR; primary manuscript writing: JR, SW and RB; content expert opinion and manuscript review/ revision: JR, KL and JG.

INSTITUTION: All research was conducted at the Royal University Hospital Sleep Disorders Centre, University of Saskatchewan, Saskatoon, Saskatchewan.

DISCLOSURES: The authors have no financial disclosures or conflicts of interest to declare.

\section{REFERENCES}

1. Public Health Agency of Canada, 2012. <www.phac-aspc.gc.ca/ hp-ps/hl-mvs/oic-oac/adult-eng.php> (2012) (Accessed January 2013). 
2. Calle EE, Thun MJ, Petrelli JM, Rodriguez C, Heath CW Jr. Body-mass index and mortality in a prospective cohort of U.S. adults. N Engl J Med 1999;341:1097.

3. Lee IM, Manson JE, Hennekens CH, Paffenbarger RS Jr. Body weight and mortality. A 27-year follow-up of middle-aged men. JAMA 1993;270:2823-8.

4. Manson JE, Willett WC, Stampfer MJ, et al. Body weight and mortality among women. N Engl J Med 1995;333:677-85.

5. Flegal KM, Kit BK, Orpana H, Graubard BI. Association of allcause mortality with overweight and obesity using standard body mass index categories: A systematic review and meta-analysis. JAMA 2013;309:71-82.

6. El-Solh A, Sikka P, Bozkanat E, Jaafar W, Davies J. Morbid obesity in the medical ICU. Chest 2001;120:1989-97.

7. Goulenok C, Monchi M, Chiche JD, Mira JP, Dhainaut JF, Cariou A. Influence of overweight on ICU mortality: A prospective study. Chest 2004;125:1441-5.

8. Neville AL, Brown CV, Weng J, Demetriades D, Velmahos GC. Obesity is an independent risk factor of mortality in severely injured blunt trauma patients. Arch Surg 2004;139:983-7.

9. Brown CV, Neville AL, Rhee P, Salim A, Velmahos GC, Demetriades D. The impact of obesity on the outcomes of 1,153 critically injured blunt trauma patients . J Trauma 2005;59:1048,51.

10. Nasraway SA Jr, Albert M, Donnelly AM, Ruthazer R, Shikora SA, Saltzman E. Morbid obesity is an independent determinant of death among surgical critically ill patients. Crit Care Med 2006;34:964-70.

11. Bochicchio GV, Joshi M, Bochicchio K, Nehman S, Tracy JK, Scalea TM. Impact of obesity in the critically ill trauma patient: A prospective study. J Am Coll Surg 2006;203:533-8.

12. Bercault N, Boulain T, Kuteifan K, Wolf M, Runge I, Fleury JC. Obesity-related excess mortality rate in an adult intensive care unit: A risk-adjusted matched cohort study. Crit Care Med 2004;32:998-1003

13. King P, Mortensen EM, Bollinger M, et al. Impact of obesity on outcomes for patients hospitalised with pneumonia. Eur Respir J 2013;41:929-34.

14. Kumar G, Majumdar T, Jacobs ER, et al. Outcomes of morbidly obese patients receiving invasive mechanical ventilation: A nationwide analysis. Chest 2013;144:48-54.

15. Pickkers P, de Keizer N, Dusseljee J, Weerheijm D, van der Hoeven JG, Peek N. Body mass index is associated with hospital mortality in critically ill patients: An observational cohort study. Crit Care Med 2013;41:1878-83.

16. Martino JL, Stapleton RD, Wang M, et al. Extreme obesity and outcomes in critically ill patients. Chest 2011;140:1198-206.
17. Akinnusi ME, Pineda LA, El Solh AA. Effect of obesity on intensive care morbidity and mortality: A meta-analysis. Crit Care Med 2008;36:151-8.

18. Pischon T, Boeing H, Hoffmann K, et al. General and abdominal adiposity and risk of death in Europe. N Engl J Med 2008;359:2105.

19. Zhang X, Shu XO, Yang G, et al. Abdominal adiposity and mortality in Chinese women. Arch Intern Med 2007;167:886-92.

20. Paolini JB, Mancini J, Genestal M, et al. Predictive value of abdominal obesity vs. body mass index for determining risk of intensive care unit mortality. Crit Care Med 2010;38:1308-14.

21. Hsieh SD, Yoshinaga H, Muto T. Waist-to-height ratio, a simple and practical index for assessing central fat distribution and metabolic risk in Japanese men and women. Int J Obes Relat Metab Disord 2003;27:610-6.

22. Sayeed MA, Mahtab H, Latif ZA, et al. Waist-to-height ratio is a better obesity index than body mass index and waist-to-hip ratio for predicting diabetes, hypertension and lipidemia. Bangladesh Med Res Counc Bull 2003;29:1-10.

23. Knaus WA, Draper EA, Wagner DP, Zimmerman JE. APACHE II: A severity of disease classification system. Crit Care Med 1985;13:818-29.

24. Adams KF, Schatzkin A, Harris TB, et al. Overweight, obesity, and mortality in a large prospective cohort of persons 50 to 71 years old. N Engl J Med 2006;355:763.

25. Sakr Y, Madl C, Filipescu D, et al. Obesity is associated with increased morbidity but not mortality in critically ill patients. Intensive Care Med 2008;34:1999.

26. De Jong A, Jung B, Chanques G, Jaber S, Molinari N. Obesity and mortality in critically ill patients: Another case of the Simpson paradox? Chest 2012;141:1637-8.

27. Morris AE, Stapleton RD, Rubenfeld GD, Hudson LD, Caldwell E, Steinberg KP. The association between body mass index and clinical outcomes in acute lung injury. Chest 2007;131:342-8.

28. Ray DE, Matchett SC, Baker K, Wasser T, Young MJ. The effect of body mass index on patient outcomes in a medical ICU. Chest 2005;127:2125-31.

29. Hogue CJ, Stearnsm J, Colantuoni E, et al. The impact of obesity on outcomes after critical illness: A meta-analysis. Intensive Care Med 2009;35:1152-70.

30. O'Brien JM Jr, Welsh CH, Fish RH, Ancukiewicz M, Kramer AM; National Heart, Lung, and Blood Institute Acute Respiratory Distress Syndrome Network. Excess body weight is not independently associated with outcome in mechanically ventilated patients with acute lung injury. Ann Intern Med 2004;140:338-45.

\section{APPENDIX A}

\section{Full multivariable logistic regression models for each categorical outcome, with waist-to-height ratio (WHR) and body} mass index (BMI) as respective key predictors

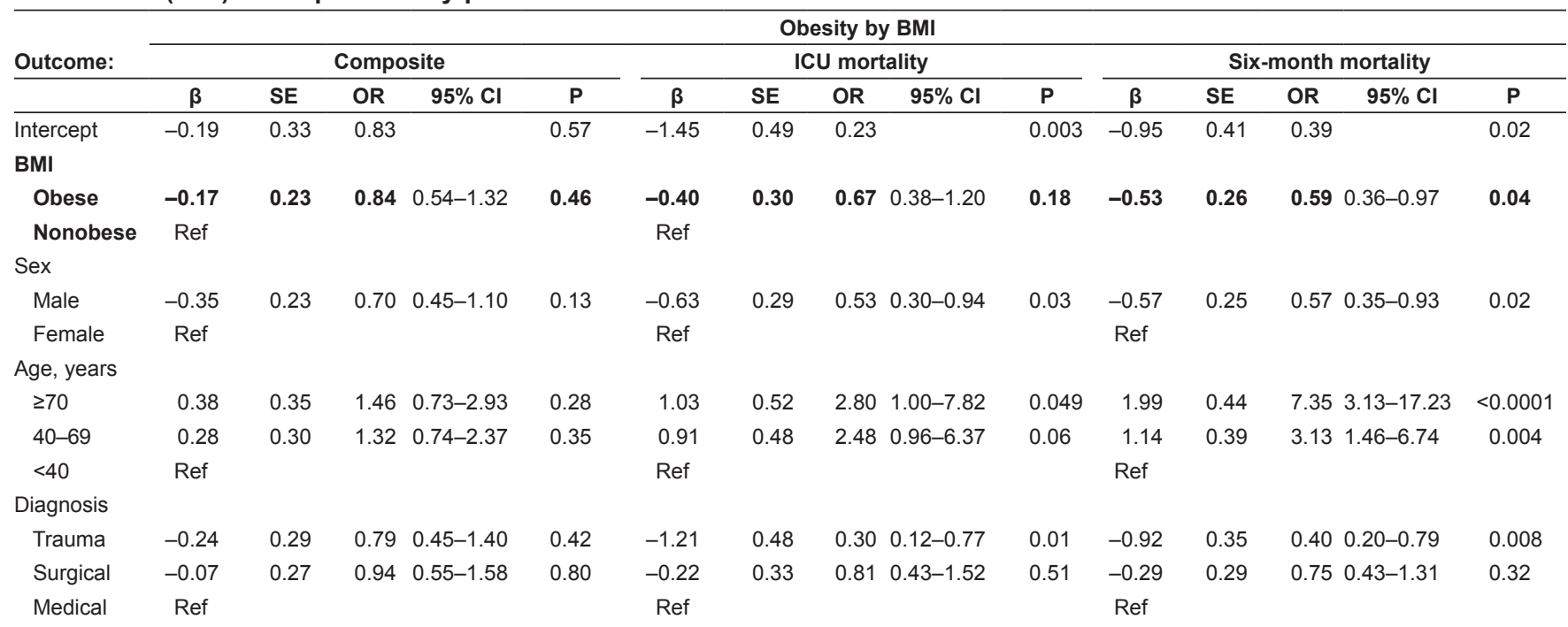


APPENDIX A - CONTINUED

I. Full multivariable logistic regression models for each categorical outcome, with waist-to-height ratio (WHR) and body mass index (BMI) as respective key predictors

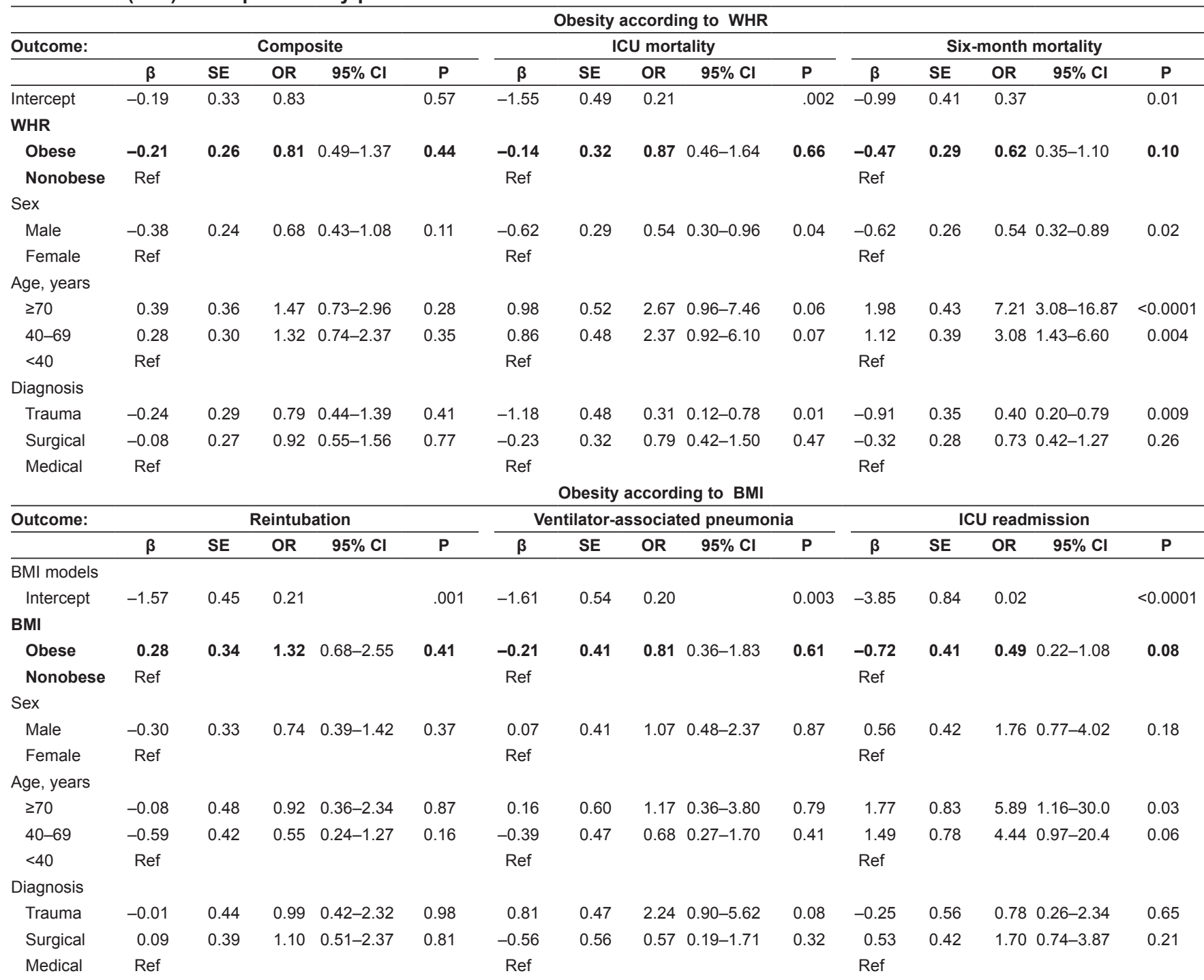

Obesity according to WHR

\begin{tabular}{|c|c|c|c|c|c|c|c|c|c|c|c|c|c|c|c|}
\hline \multirow[t]{2}{*}{ Outcome: } & \multicolumn{5}{|c|}{ Reintubation } & \multicolumn{5}{|c|}{ Ventilator-associated pneumonia } & \multicolumn{5}{|c|}{ ICU readmission } \\
\hline & $\beta$ & SE & OR & $95 \% \mathrm{Cl}$ & $\mathbf{P}$ & $\beta$ & SE & OR & $95 \% \mathrm{Cl}$ & $\mathbf{P}$ & $\beta$ & SE & OR & $95 \% \mathrm{Cl}$ & $\mathbf{P}$ \\
\hline Intercept & -1.64 & 0.46 & 0.19 & & 0.0003 & -1.58 & 0.55 & 0.21 & & 0.004 & -3.73 & 0.83 & 0.02 & & $<0.0001$ \\
\hline \multicolumn{16}{|l|}{ WHR } \\
\hline Obese & 0.56 & 0.37 & 1.75 & $0.85-3.60$ & 0.13 & -0.26 & 0.52 & 0.77 & $0.28-2.15$ & 0.62 & -1.48 & 0.63 & 0.23 & $0.07-0.79$ & 0.02 \\
\hline Nonobese & Ref & & & & & Ref & & & & & Ref & & & & \\
\hline \multicolumn{16}{|l|}{ Sex } \\
\hline Male & -0.19 & 0.34 & 0.82 & $0.42-1.62$ & 0.58 & 0.02 & 0.41 & 1.02 & $0.45-2.31$ & 0.96 & 0.36 & 0.43 & 1.44 & $0.62-3.33$ & 0.39 \\
\hline Female & Ref & & & & & Ref & & & & & Ref & & & & \\
\hline \multicolumn{16}{|l|}{ Age, years } \\
\hline$\geq 70$ & -0.16 & 0.48 & 0.85 & $0.33-2.19$ & 0.74 & 0.18 & 0.61 & 1.20 & $0.37-3.96$ & 0.76 & 1.81 & 0.83 & 6.13 & $1.22-30.91$ & 0.03 \\
\hline $40-69$ & -0.64 & 0.43 & 0.53 & $0.23-1.21$ & 0.13 & -0.40 & 0.46 & 0.67 & $0.27-1.65$ & 0.38 & 1.53 & 0.77 & 4.62 & $1.02-20.15$ & 0.048 \\
\hline$<40$ & Ref & & & & & Ref & & & & & Ref & & & & \\
\hline \multicolumn{16}{|l|}{ Diagnosis } \\
\hline Trauma & -0.001 & 0.44 & 1.00 & $0.42-2.35$ & 1.00 & 0.79 & 0.47 & 2.21 & $0.88-5.55$ & 0.09 & -0.31 & 0.56 & 0.73 & $0.24-2.20$ & 0.58 \\
\hline Surgical & 0.13 & 0.39 & 1.14 & $0.53-2.45$ & 0.75 & -0.58 & 0.56 & 0.56 & $0.19-1.67$ & 0.30 & 0.46 & 0.42 & 1.58 & $0.69-3.61$ & 0.28 \\
\hline Medical & Ref & & & & & Ref & & & & & Ref & & & & \\
\hline
\end{tabular}


APPENDIX A - CONTINUED

II. Full multivariable negative binomial regression models for count outcomes, with waist-to-height ratio (WHR) and body mass index (BMI) as respective key predictors

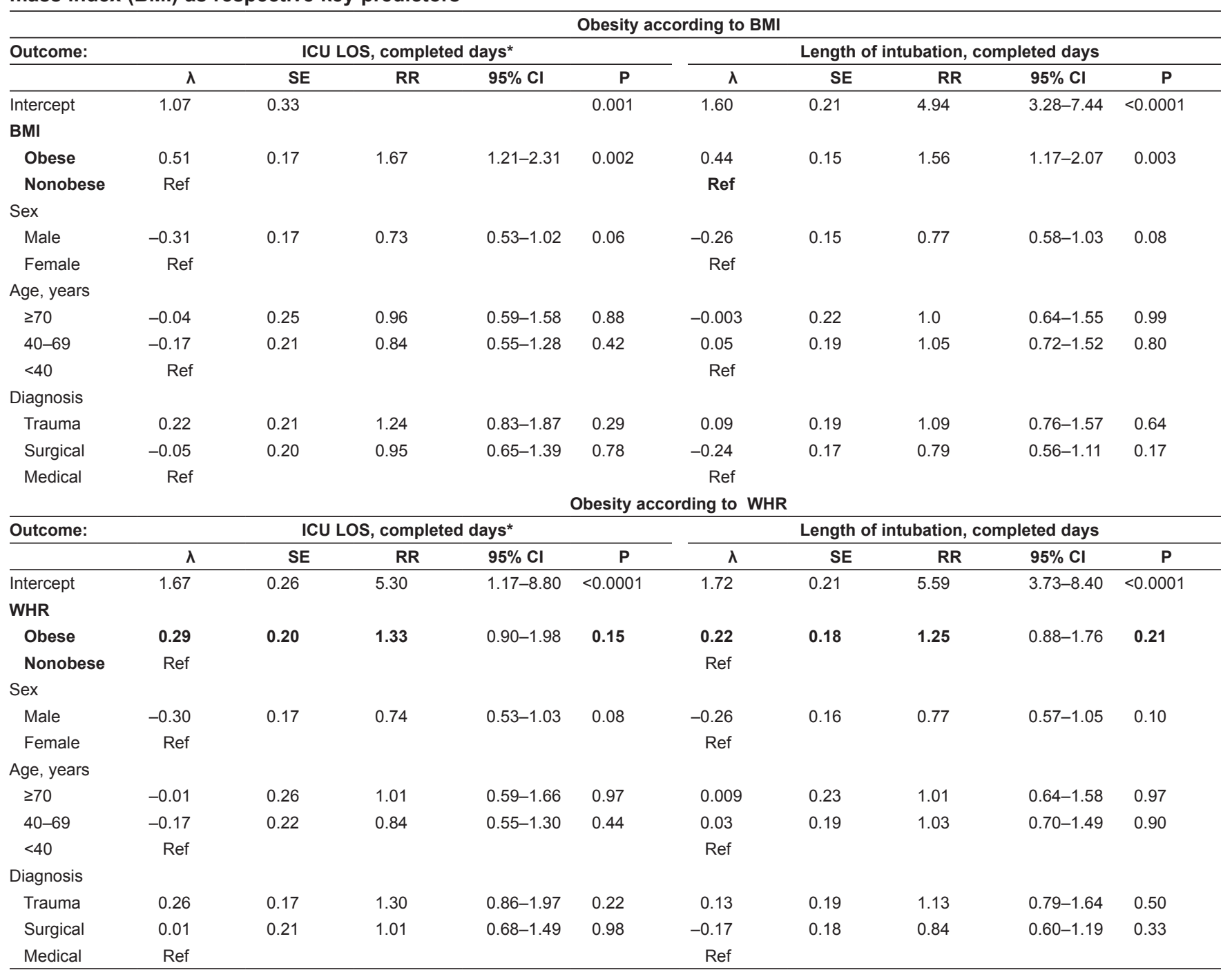

BMI: obese $\geq 30 \mathrm{~kg} / \mathrm{m}^{2}$, nonobese $18.5 \mathrm{~kg} / \mathrm{m}^{2}$ to $29.9 \mathrm{~kg} / \mathrm{m}^{2}$; WHR: obese $>75$ th percentile, nonobese $\leq 75$ th percentile. *Zero-truncated negative binomial model used as inclusion criteria required a minimum $24 \mathrm{~h}$ admission. ICU Intensive care unit; LOS Length of stay; Ref Reference group; RR Rate ratio 


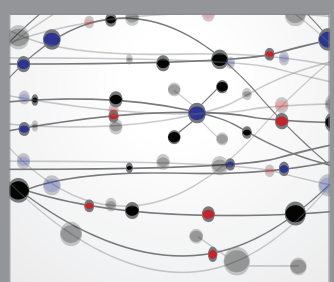

The Scientific World Journal
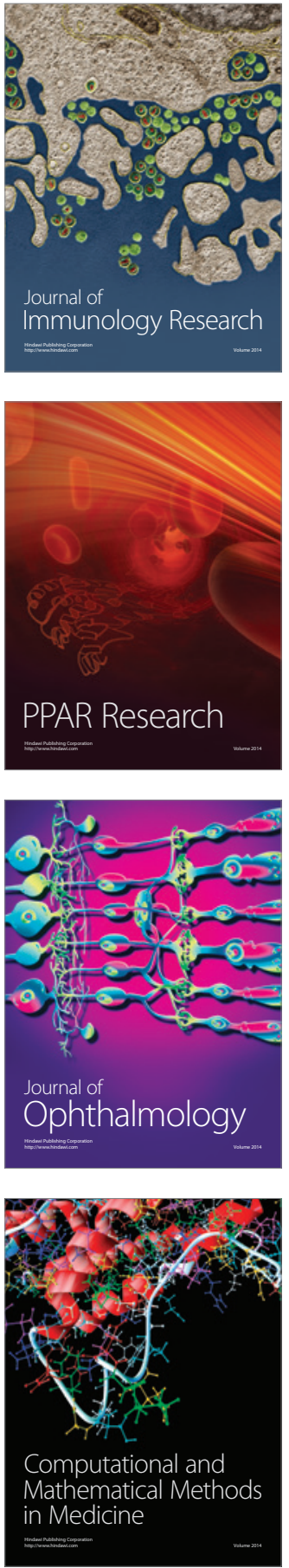

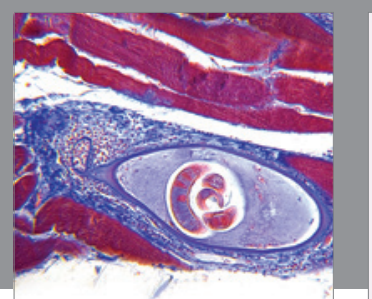

Gastroenterology Research and Practice

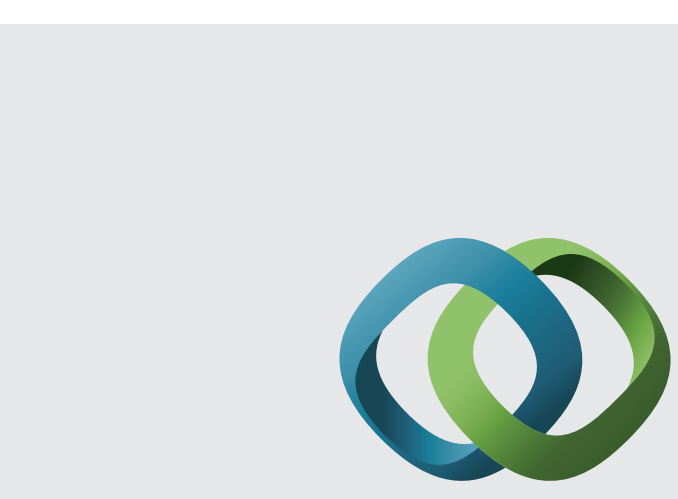

\section{Hindawi}

Submit your manuscripts at

http://www.hindawi.com
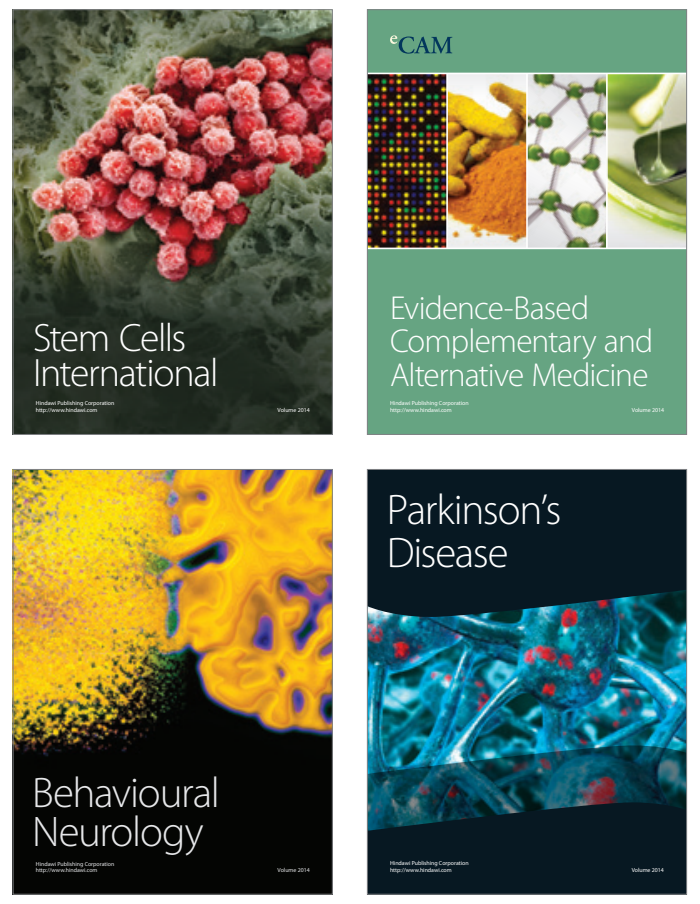
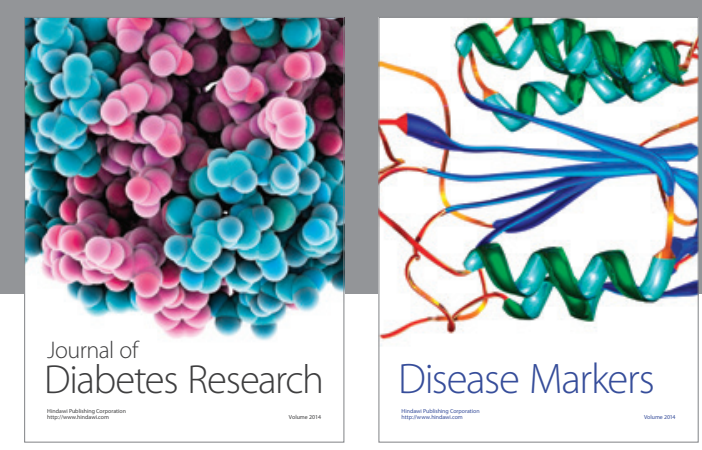

Disease Markers
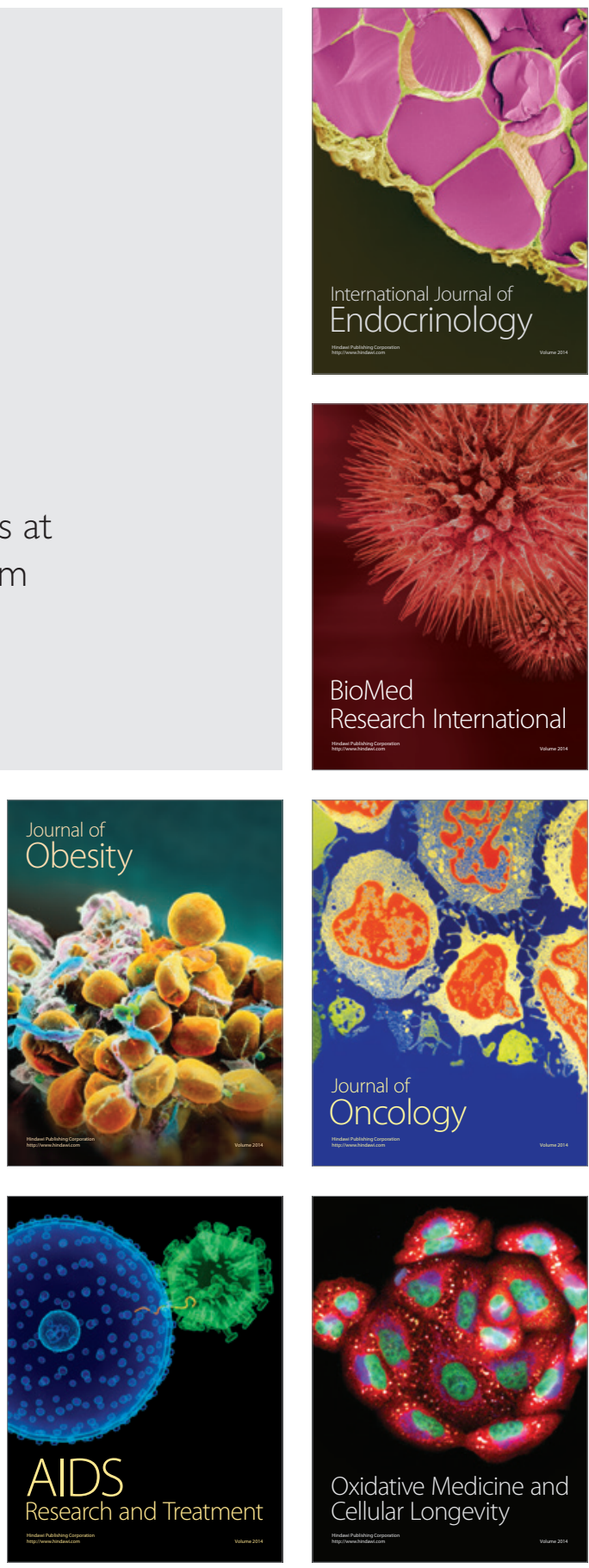